\title{
Content-based language teaching: Convergent concerns across divergent contexts
}

Language Teaching Research I5(3) 279-288

(C) The Author(s) 2011 Reprints and permission: sagepub. co.uk/journalsPermissions.nav DOI: I0.1 I77/I362I688II40II50 Itr.sagepub.com @SAGE

\section{Roy Lyster and Susan Ballinger}

McGill University, Canada

\begin{abstract}
This article serves as the introduction to this special issue of Language Teaching Research on content-based language teaching (CBLT). The article first provides an illustrative overview of the myriad contexts in which CBLT has been implemented and then homes in on the five studies comprising the special issue, each conducted in a distinct instructional setting: two-way Spanish-English immersion in the USA, English-medium 'nature and society' lessons taught at a middle school in China, English-medium math and science classes in Malaysian high schools, English-medium history classes in high schools in Spain, and 'sheltered instruction' classes for English language learners in US schools. In spite of such divergent contexts, the five studies converge to underscore the pivotal role played by teachers in CBLT and the concomitant need for professional development to support them in meeting some of the challenges specific to CBLT.
\end{abstract}

\section{Keywords}

content-based language teaching (CBLT), immersion, content and language integrated learning (CLIL), content-based instruction

\section{Introduction}

This special issue of Language Teaching Research is devoted to content-based language teaching (CBLT). CBLT is an instructional approach in which non-linguistic curricular content such as geography or science is taught to students through the medium of a language that they are concurrently learning as an additional language. The additional languages promoted by CBLT run the gamut from second and foreign languages to

\section{Corresponding author:}

Roy Lyster, McGill University, 3700 McTavish Street, Montreal, Quebec, H3A IY2, Canada

Email: roy.lyster@mcgill.ca 


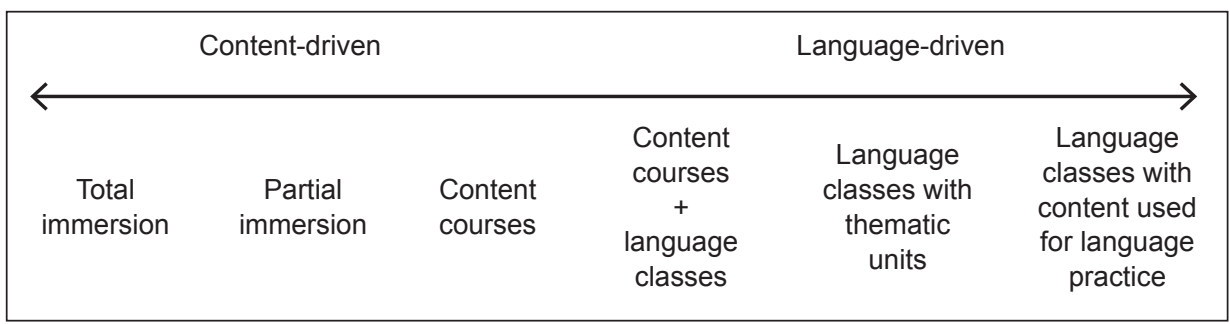

Figure I Range of CBLT settings

Source: adapted from Met, 1998, p. 4 I

regional, heritage, and indigenous languages. In this introductory article, we first emphasize the wide range of contexts in which CBLT is used, and then zero in on the diverse contributions to this special issue and the pedagogical concerns that converge to connect them.

\section{Divergent contexts}

Met (1998) described a range of CBLT settings along a continuum (see Figure 1) varying from 'content-driven programs', such as immersion, to 'language-driven programs', which include language classes either based on thematic units or with frequent use of content for language practice. Content-driven programs promote language and literacy development through subject-matter learning and assess both content knowledge and language development in substantive ways. In contrast, language-driven programs focus on the development of target language proficiency but entail no high-stakes assessment of content knowledge. Towards the middle of the continuum are program models in which students study one or two subjects in the target language, usually in tandem with a foreign language or language arts class. An example of the latter would be the English-medium CBLT programs implemented in China (see Cheng et al., 2010; Hoare, 2010), which select subjects that are not part of the formal curriculum such as 'nature and society' and 'science and life' to be taught usually for two lessons per week. Another example is the adjunct format adopted at the post-secondary level in which students are integrated into a content course offered for native speakers 'but sheltered as a group in a separate credit language course related to the content course' (Burger \& Chrétien, 2001, p. 85). Also at the post-secondary level are Italian geography courses in the USA that aim to facilitate students' transition to more advanced courses in Italian language and literature and for which they receive credit in Italian but not in geography (Musumeci, 1996; Rodgers, 2006). Content-based EFL courses have also been introduced at post-secondary levels in Japan where a task-based approach to CBLT has shown considerable promise for teaching courses in comparative culture (Lingley, 2006) and for providing a refreshing antidote to teacher-led lecture formats observed in geography and sociology courses (Moriyoshi, 2010).

School-based language immersion programs aim for additive bilingualism by providing a significant portion (usually at least $50 \%$ during elementary school years) of students' subject-matter instruction through the medium of an additional language. Such programs have been adopted in some countries to promote the learning of a second 
official language. Examples of these include French immersion in Canada (e.g. Lazuruk, 2007), Swedish immersion in Finland (e.g. Södergård, 2008), Catalan immersion in Spain (e.g. Arnau, 2000), Basque immersion in Spain (Cenoz, 2008), and Irish immersion in Ireland (e.g. Ó Baoill, 2007). Many such immersion programs are often identified simply as programs taught through the medium of a given language, such as Gaelicmedium schools in Scotland or Irish-medium schools in Ireland. In still other contexts, school-based CBLT programs have been designed to deliver at least half the curriculum through the medium of regional languages such as Breton and Occitan in France (Rogers $\&$ McLeod, 2006) or indigenous languages such as Maori in New Zealand (Reedy, 2000) and Hawaiian in the USA (Luning \& Yamauchi, 2010). Also in the USA are a rapidly growing number of two-way immersion programs, which normally integrate a similar number of children from two different mother-tongue backgrounds (e.g. Spanish and English) and provide curricular instruction in both languages (Lindholm-Leary, 2001).

The design of two-way immersion programs is especially appealing for their integration of first and second language users of two different target languages, a phenomenon reflecting the demographics of other contexts of CBLT as well. For example, Basque-medium schools in the Basque Country were originally created as a language maintenance program for native speakers of Basque, but are now regarded 'as both total immersion programs for native Spanish-speaking students and first language maintenance programs for native Basque speakers' (Cenoz, 1998). Catalan immersion programs in Catalonia were designed for native speakers of Spanish but, for a school to be designated as an immersion school, as many as 30\% of its students can have Catalan as their family language (Artigal, 1997). Similarly, in the case of Wales, 'A Welsh-medium school usually contains a mixture of first language Welsh pupils, relatively fluent second language Welsh speakers, plus those whose out-of-school language is English (i.e. "immersion" pupils)' (Baker, 1993, p. 15; for a similar description of Irish-medium education in Ireland, see Hickey, 2001). Even in some English-speaking school boards in the province of Quebec, where Canadian French immersion programs were first launched with homogenous groups of English-speaking children, increasingly heterogeneous classrooms consist of French-dominant, English-dominant, and French-English bilingual students (Lyster et al., 2009).

Also rapidly growing are content and language integrated learning (CLIL) programs across Europe and elsewhere (see Coyle, 2007; Mehisto et al., 2008). In some respects, CLIL and immersion programs are similar insofar as both aim to integrate content and language instruction. Throughout Europe, however, where immersion programs target a wide range of languages that often have official status as second and/or regional languages, the focus of CLIL is on foreign languages, which in most programs is English (Lasagabaster \& Sierra, 2010). Also, in Europe there are European Schools (Housen, 2002) that aim to foster multilingualism among linguistically diverse groups of students by ensuring literacy development in their respective L1 and high levels of L2 proficiency in either French, English, or German, which are used as the medium of instruction in later grades to teach subjects such as history, geography, and economics.

English as an international language is the main target of CBLT in a variety of programs ranging from English immersion in Japan (Bostwick, 2001) to late immersion in Hong Kong (Hoare \& Kong, 2008), as well as International Schools such as the one described by Spezzini (2005) in Paraguay. The adoption of English as a medium of 
instruction in higher education, as described by Coleman (2006) in the European context, also entails CBLT. Many language teacher education programs around the world also involve CBLT as students are required to develop proficiency in the target language while taking pedagogy and subject content courses taught in that language. An example is the English language teacher education program in Hong Kong described by Hoare et al. (2008) where the language objectives are mapped onto the content curriculum. The scope of CBLT grows exponentially when its defining characteristics also encompass contexts of English for academic purposes at secondary and post-secondary levels as well as contexts of language training in the workplace.

School-based contexts where newcomers to a country are learning the new language while also studying curricular content through that language, yet without necessarily any first language support, also entail CBLT. Such is the case of content-based ESL and 'sheltered instruction' in the USA. In content-based ESL, 'teachers seek to develop the students' English language proficiency by incorporating information from the subject areas that students are likely to study,' and sheltered instruction entails content courses for ESL learners taught normally by content (rather than ESL) specialists (Echevarría et al., 2008, p. 13).

CBLT thus crosses a wide range of international contexts and instructional settings, including elementary, secondary and post-secondary institutions. In spite of the tremendous differences across these contexts (some including majority-language and others minority-language students), there are some common pedagogical issues that arise at the interface of language and content teaching. As Wesche (2001, p. 1) argued, 'the contexts have much in common, each involving learners struggling to master academic concepts and skills through a language in which they have limited proficiency, while at the same time striving to improve that proficiency.' She suggested that learners' efforts in this endeavor 'can be facilitated by considerably good teaching.' Drawing on classroom research, this special issue aims to identify effective pedagogical practices that are apt to facilitate the learning of an additional language while learning curricular content through that language. Also identified will be some of the obstacles that stand in the way of the seemingly paradoxical endeavor of learning and teaching language through non-linguistic curricular content.

\section{Convergent concerns}

Among the many contexts of CBLT evoked in the previous section, this special issue focuses on five distinct instructional settings:

- a two-way Spanish-English immersion school in the USA;

- three 'nature and society' lessons taught in English at a middle school in the People's Republic of China;

- English-medium mathematics and science classes in two Malaysian high schools;

- CLIL classes in Spain at two high schools where history is taught through the medium of English; and

- sheltered instruction for English language learners in US schools. 
The special issue opens with a cross-sectional study by Susan Ballinger and Roy Lyster conducted in two-way immersion classrooms at three different grade levels (Grades 1,3, and 8). The aim of their study was to identify factors influencing the choices made by students and teachers to speak either English or Spanish and, in particular, to diverge from Spanish when it was the language of instruction. Similar to previous research in two-way immersion settings, students showed a general preference for English, regardless of their language background, particularly in interactions with peers. This means that only the Spanish L1 students were extensively practicing their L2 with their peers and that their opportunities for L1 enrichment were mainly limited to interactions with teachers. Interestingly, the results of their study suggest that teachers' expectations played a pivotal role in determining their students' language choices. For example, the Grade 1 teachers did not push English L1 students to speak Spanish in any context, and these students were never observed speaking Spanish. The Grade 3 Spanish teacher required her students to speak to her in Spanish, and they did so in almost every situation, although they rarely spoke Spanish with classmates, and she did not expect them to. The Grade 8 Spanish language arts teacher was the only teacher to require his students to speak to each other in Spanish, and they spoke more Spanish to each other than in any other classroom. Their study revealed also that two-way immersion students are sensitive to other students' language needs and that, regardless of their own Spanish language proficiency, they make efforts to accommodate the needs of Spanish-dominant newcomers. Ballinger and Lyster call for research into the types and formats of collaborative tasks that would create optimal conditions for using the non-English language in peer interaction and, thus, more opportunities for reciprocal L2 learning among immersion students with the goal of giving all students, regardless of their language background, opportunities to practice and enrich their knowledge of the non-English language.

The study by Stella Kong and Philip Hoare addresses a well-known dilemma in CBLT: how to make subject-matter content comprehensible to learners, whose knowledge of the language of instruction is only partial, without simplifying the curricular content to the point of shortchanging students. The perennial question of how to effectively integrate language and content in CBLT can perhaps be best addressed by the metaphor of scaffolding, which brings to the forefront the central role played by teacher discourse. Teacher scaffolding entails questions and feedback designed to support language learning while fostering students' cognitive engagement with content in a language they know only partially. Kong and Hoare define cognitive content engagement as 'the cognitive interaction of the student with an appropriately challenging academic content level through activities that require sufficient depth of processing.' Through a careful discourse analysis of three lessons given by the same teacher, Kong and Hoare argue that the structure of the more effective lessons was cyclical rather than linear, which enabled the teacher to explore content with students from multiple perspectives rather than only covering a list of facts. The teacher strove to convey the knowledge relationship of classification (of animals) by aiming at a level of technical academic knowledge rather than at a level of common sense knowledge. She progressively built on students' knowledge while pushing them to engage in deeper levels of processing and knowledge reproduction. One way in which she did this was by exploiting feedback moves in the predominantly 
initiation-response-feedback classroom-interaction pattern in ways that required students to elaborate their ideas more fully. While illustrating how some CBLT lessons are better than others at promoting in-depth exploration of content, Kong and Hoare's study provides evidence that CBLT lessons can be well planned in ways that fuse both language and content objectives while compromising neither the scope of academic content nor the depth of processing.

May Tan's article reveals the challenges of fusing language and content in CBLT contexts where math and science teachers are trained subject specialists expected to seek language support beyond class time from English language teachers in the same school. She illustrates how collaboration between content and language teachers was thwarted not only by constraints such as exam-driven curricula and minimal training in CBLT but also by their own perceptions of being 'only content teachers' or 'only language teachers'. Her findings are reminiscent of studies conducted in other CBLT contexts, including mainstream classrooms where, in spite of the pairing up of a subject-matter specialist with an ESL specialist in the same classroom, institutional and wider societal agendas militate against equitable integration of content and language by investing language with less status relative to content knowledge (Creese, 2002, 2006; Arkoudis, 2006).

Tan's classroom observations did not reveal that teachers engaged in the kind of indepth exploration of content that Kong and Hoare noted in some of the more effective lessons that they described. Tan concludes by making an urgent appeal for professional development initiatives to provide support for math and science teachers to experiment with more learner-centered and inquiry-based pedagogies and to develop other such strategies that would engage their students more fully in the discourses of math and science. At this point, however, the teaching of math and science through the medium of English in Malaysian schools can be seen as a relatively short-lived initiative. Whereas English-medium instruction in these subjects began only in 2002, a return to Malaymedium instruction in math and science will take effect in 2012, following an announcement in 2009 by the Malaysian Ministry of Education, based on studies reporting that 'the teaching of maths and science has been problematic and has not improved proficiency' (Hashim, 2009, p. 48). Tan's study stands as a cautionary example of the issues that can arise when CBLT programs are adopted to teach through the medium of English as an international language before content and language teachers are adequately prepared for the major overhaul of instructional practices engendered by such a policy change, especially in content areas involving high-stakes assessment.

Much research in immersion and other CBLT contexts has focused on oral language use (by both teachers and students) and on students' development of oral proficiency in the target language. Diverging from this trend, Rachel Whittaker, Ana Llinares, and Anne McCabe analyse the development of written discourse in the context of a high school CLIL program in Spain. To do so, they draw on Systemic Functional Linguistics, which has proven useful for studying academic language development through its emphasis on how linguistic features of disciplinary texts construe particular kinds of meanings (e.g. Schleppegrell et al., 2004). Their longitudinal study of texts written by the same group of students in history classes over a four-year period examined text coherence through detailed analyses of the structure of noun phrases and their recoverability via various referential elements. As might be expected over a four-year period, 
development was noted in the students' ability to introduce and track participants (i.e. actants in narratives). Specifically, through increased textual coherence and cohesion, these Spanish-speaking students showed some signs of development toward an appropriate academic register required for writing history texts in English. The authors suggest that these developments did not necessarily result from any explicit instruction in academic writing and are more likely attributable to the students' accumulated exposure to English and their cognitive growth over the four years. For even greater developmental outcomes, Whittaker et al. make a convincing argument for integrating a more explicit focus on 'language as a meaning-making resource' into CBLT classes.

A common thread running through most studies in this special issue is the important role that is played by professional development in the continued success of CBLT. The call for increased professional development is urgent because the odds are such that most teachers working in CBLT contexts have been trained to teach either language or a nonlanguage subject area, but not both, even though for years there has been a growing consensus in the research literature that, for CBLT to reach its full potential for maximizing integrated learning, it must be language-rich and discourse-rich (e.g. Genesee, 1987; Swain, 1988, 1996; Allen et al., 1990; Musumeci, 1996; Duff, 2001; Dalton-Puffer, 2007; Lyster; 2007; Hoare \& Kong, 2008). This is expected to change as teacher education programs continue to respond to the growing need for educators to teach both language and content in the spirit of language across the curriculum, which underpins many current educational innovations and reform movements. One such professional development initiative is the Sheltered Instruction Observation Protocol (SIOP) Model that has been used in an extended program of research synthesized in this special issue's final article by Deborah Short, Jana Echevarría, and Catherine Richards-Tutor.

Use of the SIOP Model for professional development provides teachers with guidance in implementing subject area curriculum, in ways that maintain grade-level objectives, to students learning through a second language. It includes techniques that make the content material accessible (e.g. use of manipulatives, graphic organizers, multimedia resources) and that develop literacy skills as well as skills specific to second language learners (e.g. reading comprehension strategies, oral practice activities, academic vocabulary development, opportunities for peer interaction). The SIOP Model requires clear identification of both content and language objectives and provides sample lessons that each end with a review of key vocabulary and content concepts.

Short et al. review three studies undertaken to assess the effects of the SIOP Model on students' academic language and literacy skills. Overall, students whose teachers had been trained in using the SIOP Model performed better on measures of reading, writing, and oral proficiency than students whose teachers had not. The authors conclude that the SIOP Model's attention to language development influenced student English language performance and improved the quality of content area teaching, but that these positive effects varied across studies as a function of the overall quality of the professional development. More successful implementation occurred in school contexts benefiting already from an established culture of cross-disciplinary collaboration, which facilitated the ongoing provision of coaching support through feedback. Greater fidelity of implementation was also observed in contexts that were less constrained by time restrictions, leading Short et al. to conclude that 'school reform policies need to anticipate and plan for 
such time frames and ought to provide not only a series of workshops but also additional support through coaching, lesson planning, and other technical assistance.'

The five studies comprising this special issue together underscore the pivotal role that is played by teachers in CBLT and the concomitant need for professional development to support them in meeting some of the challenges specific to CBLT. The decisive role of teachers in CBLT is highlighted in these studies by (1) the influence that their expectations are observed to have on students' language choices and (2) their ability to structure lessons that fuse language and content in ways that lead students to higher levels of cognitive engagement with content. Other key roles suggested by these studies that teachers can take on to improve CBLT include systematic implementation of (3) collaborative tasks to create opportunities for reciprocal language learning, (4) guidance to support students' development of written discourse in content areas, and (5) learner-centered as well as inquiry-based pedagogies that engage students more fully in discipline-specific discourses. Finally, to improve the quality of CBLT in these ways through professional development, the training itself needs to be of high quality, which is contingent upon (6) institutional commitments to provide teachers with sufficient time and sustainable opportunities for peer coaching in the spirit of cross-disciplinary collaboration.

This special issue fittingly closes with a book review by Patsy Lightbown of Tara Fortune's (2010) publication, Struggling learners and language immersion education: Research-based, practitioner-informed responses to educators'top questions. The question of whether immersion programs and other types of optional CBLT programs are suitable for all learners is a pervasive one. Like other concerns addressed throughout this special issue, many of the proposed solutions lie in more systematic professional development that is both research-based and practitioner-informed. Fortune's book is an exemplary resource for such professional development and, in her review, Lightbown highlights the book's relevance to contexts of CBLT other than only immersion, thus lending support to our goal for this special issue to explore the convergence of concerns across divergent contexts of CBLT.

\section{References}

Allen, P., Swain, M., Harley, B., \& Cummins, J. (1990). Aspects of classroom treatment: Toward a more comprehensive view of second language education. In B. Harley, P. Allen, J. Cummins, \& M. Swain (Eds.), The development of second language proficiency (pp. 57-81). Cambridge: Cambridge University Press.

Arkoudis, S. (2006). Negotiating the rough ground between ESL and mainstream teachers. International Journal of Bilingual Education and Bilingualism, 9, 415-33.

Arnau, J. (2000). Catalan immersion teachers: Principles of language teaching. International Journal of Bilingual Education and Bilingualism, 3, 79-100.

Artigal, J. (1997). The Catalan immersion program. In K. Johnson \& M. Swain (Eds.), Immersion education: International perspectives (pp. 133-50). Cambridge: Cambridge University Press.

Baker, C. (1993). Bilingual education in Wales. In H. Baetens Beardsmore (Ed.), European models of bilingual education (pp. 7-29). Clevedon: Multilingual Matters.

Bostwick, M. (2001). Bilingual education of children in Japan: Year four of a partial immersion programme. In M.G. Noguchi \& S. Fotos (Eds.), Studies in Japanese bilingualism (pp. 272311). Clevedon: Multilingual Matters. 
Burger, S. \& Chrétien, S. (2001). The development of oral production in content-based second language courses at the University of Ottawa. The Canadian Modern Language Review, 58, 84-102.

Cenoz, J. (1998). Multilingual education in the Basque Country. In J. Cenoz \& F. Genesee (Eds.), Beyond bilingualism: Multilingualism and multilingual education (pp. 175-91). Clevedon: Multilingual Matters.

Cenoz, J. (Ed.). (2008). Teaching through Basque: Achievements and challenges. Special issue of Language, Culture and Curriculum, 21(1).

Cheng, L., Li, M., Kirby, J., Qiang, H., \& Wade-Woolley, L. (2010). English language immersion and students' academic achievement in English, Chinese and mathematics. Evaluation and Research in Education, 23, 151-69.

Coleman, J. (2006). English-medium teaching in European higher education. Language Teaching, $39,1-14$.

Coyle, D. (2007). Content and Language Integrated Learning: Towards a connected research agenda for CLIL pedagogies. International Journal of Bilingual Education and Bilingualism, $10,543-62$.

Creese, A. (2002). The discursive construction of power in teacher partnerships: Language and subject specialists in mainstream schools. TESOL Quarterly, 36, 597-616.

Creese, A. (2006). Supporting talk? Partnership teachers in classroom interaction. International Journal of Bilingual Education and Bilingualism, 9, 434-53.

Dalton-Puffer, C. (2007). Discourse in content and language integrated learning (CLIL) classrooms. Amsterdam/Philadelphia: John Benjamins.

Duff, P. (2001). Language, literacy, content, and (pop) culture: Challenges for ESL students in mainstream courses. The Canadian Modern Language Review, 58, 103-32.

Echevarría, J., Vogt, M., \& Short, D. (2008). Making content comprehensible for English learners: The SIOP Model. Boston, MA: Pearson Education.

Fortune, T. (with M. Menke). (2010). Struggling learners and language immersion education. Minneapolis, MN: University of Minnesota.

Genesee, F. (1987). Learning through two languages: Studies of immersion and bilingual children. Cambridge, MA: Newbury House.

Hashim, A. (2009). Not plain sailing: Malaysia's language choice in policy and education. AILA Review, 22, 36-51.

Hickey, T. (2001). Mixing beginners and native speakers in minority language immersion: Who is immersing whom? The Canadian Modern Language Review, 57, 443-74.

Hoare, P. (2010). Content-based language teaching in China: contextual influences on implementation. Journal of Multilingual and Multicultural Development, 31, 69-86.

Hoare, P. \& Kong, S. (2008). Late immersion in Hong Kong: Still stressed or making progress? In T. Fortune \& D. Tedick (Eds.), Pathways to bilingualism and multilingualism: Evolving perspectives on immersion education (pp. 242-63). Clevedon: Multilingual Matters.

Hoare, P., Kong, S., \& Bell, J. (2008). Using language objectives to integrate language and content instruction: A case history of planning and implementation challenges. Language and Education, 22, 187-205.

Housen, A. (2002). Processes and outcomes in the European Schools model of multilingual Education. Bilingual Research Journal, 26, 43-62.

Lasagabaster, D. \& Sierra, J.M. (2010). Immersion and CLIL in English: More differences than similarities. ELT Journal, 64, 367-75. 
Lazuruk, W. (2007). Linguistic, academic, and cognitive benefits of French immersion. The Canadian Modern Language Review, 63, 605-28.

Lindholm-Leary, K. (2001). Dual language education. Clevedon: Multilingual Matters.

Lingley, D. (2006). A task-based approach to teaching a content-based Canadian Studies course in an EFL context. Asian EFL Journal, 8, 122-39.

Luning, R. \& Yamauchi, L. (2010). The influences of indigenous heritage language education on students and families in a Hawaiian language immersion program. Heritage Language Journal, 7, 46-75.

Lyster, R. (2007). Learning and teaching languages through content: A counterbalanced approach. Amsterdam/Philadelphia: John Benjamins.

Lyster, R., Collins, L., \& Ballinger, S. (2009). Linking languages through a bilingual read-aloud project. Language Awareness, 18, 366-83.

Mehisto, P., Marsh, D., \& Frigols, M.J. (2008). Uncovering CLIL: Content and language integrated learning in bilingual and multilingual education. Oxford: Macmillan.

Met, M. (1998). Curriculum decision-making in content-based language teaching. In J. Cenoz \& F. Genesee (Eds.), Beyond bilingualism: Multilingualism and multilingual education (pp. 35-63). Clevedon: Multilingual Matters.

Moriyoshi, N. (2010). Content-based instruction in Japanese college classrooms: Focusing on language, content, or both? Unpublished master's thesis, McGill University, Montreal, Canada.

Musumeci, D. (1996). Teacher-learner negotiation in content-based instruction: Communication at cross-purposes? Applied Linguistics, 17, 286-325.

Ó Baoill, D. (2007). Origins of Irish-medium education: The dynamic core of language revitalization in Northern Ireland. The International Journal of Bilingual Education and Bilingualism, $10,410-27$.

Reedy, T. (2000). Te Reo Maori: The past 20 years and looking forward. Oceanic Linguistics, 39, $157-69$.

Rodgers, D. (2006). Developing content and form: Encouraging evidence from Italian contentbased instruction. The Modern Language Journal, 90, 373-86.

Rogers, V.M. \& McLeod, W. (2006). Autochthonous minority languages in public-sector primary education: Bilingual policies and politics in Brittany and Scotland. Linguistics and Education, 17, 347-73.

Schleppegrell, M., Achugar, M., \& Orteíza, T. (2004). The grammar of history: Enhancing contentbased instruction through a functional focus on language. TESOL Quarterly, 38, 67-93.

Södergård, M. (2008). Teacher strategies for second language production in immersion kindergarten in Finland. In T. Fortune \& D. Tedick (Eds.), Pathways to bilingualism and multilingualism: Evolving perspectives on immersion education (pp. 152-73). Clevedon: Multilingual Matters.

Spezzini, S. (2005). English immersion in Paraguay: Individual and sociocultural dimensions of language learning and use. International Journal of Bilingual Education and Bilingualism, 7, 79-98.

Swain, M. (1988). Manipulating and complementing content teaching to maximize second language learning. TESL Canada Journal, 6, 68-83.

Swain, M. (1996). Integrating language and content in immersion classrooms: Research perspectives. The Canadian Modern Language Review, 52, 529-48.

Wesche, M. (Ed.). (2001). French immersion and content-based language teaching in Canada. Special issue of The Canadian Modern Language Review, 58(1). 